\title{
Exploration and Practice of the Training Mode of Emerging Engineering Disciplines of Electronic Information Applied Talents in Local Colleges and Universities Against the Background of "Internet+" A Case Study of Chengdu University
}

\author{
Lijuan Xiong ${ }^{1}$ Xiujun Zhang,"* Zhiqiang Zhang ${ }^{2}$
}

\author{
${ }^{1}$ School of Fine Arts and Design, Chengdu University, Chengdu, Sichuan 610106, China \\ ${ }^{2}$ School of Computer Science, Chengdu University, Chengdu, Sichuan 610106, China \\ *Corresponding author. Email: woodszhang@cdu.edu.cn
}

\begin{abstract}
Facing the "5+5+1" industrial development needs of Chengdu, the main contradictions and problems between supply and demand of industry and talent training are analysed and discussed in-depth and extensively researched. Therefore, it innovatively reconstructed the training program and practice teaching system of the electronic information applied talents. Relying on the in-depth integration of the "Government-EnterpriseSchool-City", a high-level comprehensive practice teaching platform will be jointly built. The quality and scale of the dual-tutor teachers' team will be continuously improved, and students are encouraged and guided to continuously participate in engineering practices outside of the training program to enhance their innovative practical capabilities. At the same time, an innovation and entrepreneurship competition platform and a multilevel elite alumni class innovation training system have been built, and a cross-college and cross-professional emerging engineering "Internet + " competition team has been formed. This measure has been applied and practiced well in the Chengdu University, and can provide an effective reference for the training of electronic information applied talents in other local universities.
\end{abstract}

Keywords: Emerging engineering, Internet+, Training mode, Applied talents, Local colleges and universities.

\section{INTRODUCTION}

In order to support country's response to the environment of "great changes unseen in a century", the State Council issued the "Made in China 2025 (National Action Plan)" in May 2015 to guide the development of technology and industry. In response to the country's development strategy, the Ministry of Education put forward the construction concept of "Emerging Engineering" in

*Fund: This research was financially supported by the Special support project for education, scientific research and education reform and development of Chengdu Education Bureau (Grant No. CY2020ZG04, CY2020ZG05) and the first batch of industry university cooperation and collaborative education projects in 2021 (Grant No. 202101311035 202101299018, 202101185046)
2016, accompanied by the publication of the "Fudan Consensus"[1], "Tian Da Action"[2] and "Beijing Guide"[3], and the construction of emerging engineering is gradually launched in colleges and universities. The content of emerging engineering courses must adapt to the development of new technologies, and the talents it trained must have comprehensive application and innovation capabilities to actively use the development of new foundations, new industries, and new economies [4]. "Internet+" is driven by the development of information technology relying on new technologies such as network communication technology, artificial intelligence, big data, and the Internet of Things to transform and reform existing business formats and create new industries [5]. 
Taking Chengdu University as an example, this paper analyzes the problems existing in the training of applied talents in emerging engineering disciplines of electronic information in local universities, and explores and constructs a corresponding talent training mode. The effect is good through the implementation in the School of Electronic Information Engineering and the School of Computer Science in Chengdu University.

\section{PROBLEMS EXISTING IN THE TRAINING OF APPLIED TALENTS IN EMERGING ENGINEERING DISCIPLINES OF ELECTRONIC INFORMATION APPLIED TALENTS IN LOCAL UNIVERSITIES}

With the rapid development of the IT industry in China, new industries and business formats continue to emerge, and the demand for new technologies is increasing. Chengdu has also put forward the adaptable "5+5+1" industrial development needs in accordance with the national development strategy. The development of electronic information technology is the key development object, and higher requirements are put forward for applied talents in emerging engineering disciplines in colleges and universities. However, the updating of teaching content in colleges and universities is slow which does not meet the needs of the industry for the development of new technologies. In addition, the graduates' practical ability cannot meet the requirements of the enterprise, and a lot of training is still needed after entering the enterprise. This puts forward higher requirements for urban applied talent training. In general, the new business format requires the construction of high-quality emerging engineering disciplines in colleges and universities. The demand for applied talents also needs to efficiently improve the quality and effect of practical teaching.

\section{MAIN MEASURES AND METHODS}

\subsection{Innovatively Reconstructing the Talent Training Plan and Practice Teaching System}

In order to solve the fundamental problem of the disconnection between talent training and market demand, in-depth investigations and analysis were conducted and solutions to the development needs of Chengdu's " $5+5+1$ " industry were found. Based on the guiding ideology of "being oriented and integrating schools and cities", advancing the "four regressions", and cultivating high-quality engineering applied talents, the schoolrunning concept of "taking students as the centre" was put forward. [6] The school-running concept of "taking students as the centre, implementing the integration of 'Government-Enterprise-SchoolCity', and meeting the needs of Chengdu's local economic construction and development" was put forward. Combining the background of the emerging engineering and market demand, a wholeprocess training mode of Outcomes-based Education (OBE) with engineering certification as the core has been constructed. The college fully implements engineering certification standards in five majors. According to the requirements of electronic information posts, the close connection between professional posts and the development of local industries, the practical teaching system has been reconstructed, which is a brand-new practice teaching system with multiple-level interchange, see "Figure 1".

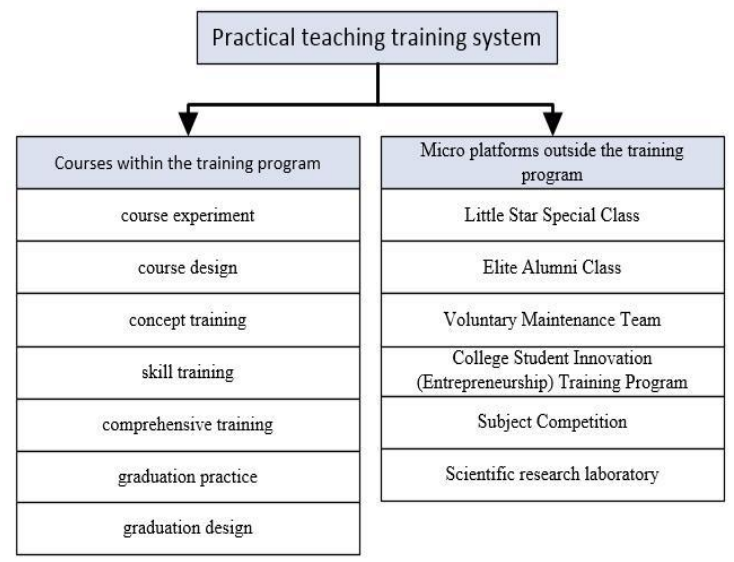

Figure 1 New practical teaching system structure.

By fully investigating the needs of Chengdu's economic development and the needs of enterprise employers, well-known enterprises and institutions in the local industry in Chengdu were visited. Questionnaires were distributed to graduates who have graduated about five years ago to learn about the settings of professional courses, practice teaching content, reform of teaching mode, graduates' competitiveness and so on. Well-known experts, scholars, and companies in the industry were invited to review the talent training programs and demonstrate the practice teaching system. A new practice teaching system was reconstructed: a practice teaching platform within the training 
program + an extended practice teaching platform outside the training program.

The practice teaching platform within the training program mainly includes: course experiment (basic experiment, professional experiment), course design, concept training, skill training, comprehensive training, graduation practice, graduation design, etc. Course experiment and course design are integrated into the corresponding course; concept training, skill training and comprehensive training are distributed in the freshman, sophomore and junior year; the graduation design adopts a dual-tutor system, where enterprise tutors and school tutors are jointly responsible for the guidance of students, making the proportion of engineering application-oriented topics reach $85 \%$.

The extended practice platform outside the training program mainly includes "Little Star Special Class", "Elite Alumni Class", Voluntary Maintenance Team, College Student Innovation and Entrepreneurship Training Program, Subject Competition, and the scientific research team of participating teachers, etc.

\subsection{Building a High-level Practice Teaching Platform}

Perfecting the construction of the practice teaching platform within the teaching and training program, the quality of the platform was continuously improved. Relying on information processing and control engineering model such as Sichuan Teaching Demonstration Center, the Sichuan Teaching Demonstration Center of Computer, Sichuan Education Department to recognize Key Laboratory, the Key Laboratory of Internet of Things of Chengdu Education Bureau and professional laboratories, course experiment, course design, intramural practical training, graduation design, etc. are completed. Industryuniversity-research practice bases, including Chengdu Chengliang Tools Group National Practice Base, Sichuan Huadi National Practice Base, Chengdu Tianxing Instrument Provincial Practice Base were established to create a shared engineering practice platform integrating education and teaching, practical training, research and development, cultivating students' engineering practice capabilities from multiple functions and angles.

A practice platform outside of the teaching and training program was strived to be built which is an extension and expansion of the practice teaching system in the training program, as well as a supplement and strengthening of the practice teaching system within the teaching program. Therefore, the university and enterprises have jointly built the "H3C IT Academy" and the university and government have jointly built the "Chenglong Valley" B area (Innovation and Entrepreneurship platform) to solve the problem of the way for students to spend a lot of time outside of class for practice and innovation. Students have participated in "Little Star Special Class ", "Elite Alumni Class", Voluntary Maintenance Team and discipline competition team after school, and also participated in various Innovation and Entrepreneurship training programs for college students at all levels, and selected some students to participate in 11 faculty research teams of the college, as well as to work with enterprises. Some students have also been selected to participate in 11-teacher research teams. Five Chengdu engineering technology research centres and joint laboratories with enterprises have been built, etc.

\subsection{Further Improving Teachers' Practical Teaching Level}

It is necessary to enhance the talent introduction, particularly the introduction of talents with the ability of engineering innovation and practice. In the past 5 years, the college has introduced 18 Double-Position teachers and 40 young doctors. At the same time, the existing teachers are cultivated and are arranged to attend: technical training, on-the-job academic upgrading, domestic and foreign further training, visits, exchanges, academic conferences, etc. Academician, Changjiang scholars and other highlevel scholars, as well as enterprise experts are invited to the university to give technical lectures to encourage teachers to apply for and participate in engineering-oriented scientific research projects and join enterprise R\&D teams to enhance their innovative and practical abilities; to encourage teachers to declare and join the collaborative education projects and teaching reform projects of the Ministry of Education to carry out teaching research, learn new teaching concepts and technologies, reform teaching methods and improve their teaching level. The college requires new $\mathrm{PhD}$ and young teachers to establish or join existing research teams on their own. 


\subsection{Stimulating and Guiding Students to Continuously Strengthen Their Creative and Practical Skills}

Through various incentive measures, students are encouraged to make full use of their spare time to participate in extended practical projects. Students are provided with multi-level and allround practical exercises such as "Practical Teaching System within the Training Program + Extended Practical Teaching System", "Intramural and Extramural Practice + Innovation and Entrepreneurship Competition + Project Practice", which effectively solve the problems of insufficient practical ability cultivation within the training program and ineffective use of students' spare time. Basically, the whole students participated in the extended practical sessions.

The college provides support in terms of projects, funds, venues and teachers, and encourages students "to get out of the dormitory, out of games and out of chatting, into the open lab, into the Innovation and Entrepreneurship centre, into the research team and into the innovation practice project." The college has formulated relevant systems: scholarship evaluation and excellent student evaluation, in which students can get extra points for participating in the extramural scientific innovation activities, and all students are required to apply for the university-level college students' innovation and entrepreneurship training program, and publicize and guide important events such as the China International "Internet Plus" College Students' Innovation and Entrepreneurship Competition, the "Challenge Cup" National College Students' Extracurricular Academic Science and Technology Works Competition, the National College Students' Service Outsourcing Innovation and Entrepreneurship Competition, and the Blue Bridge Cup National Software and Information Technology Professionals Competition to ensure that the participation rate of students in disciplinary competitions reaches over $65 \%$.

\subsection{Improving the Discipline Competition and the Innovation Cultivation Model of Elite Alumni Class}

A practice platform for the Emerging Engineering "Internet Plus" Innovation and Entrepreneurship Competition has been built, which consists of two parts: the internal teaching materials for the Emerging Engineering "Internet Plus" Innovation and Entrepreneurship Competition and the online teaching platform. The teaching team's experience of the competition over the past 10 years has been summarized, formed an effective guidance method and provided abundant materials. The web platform relies on the construction of super network teaching platform, which includes the introduction of key competitions, creative thinking and design, competition project management and product presentation, introduction of competition tools and software, excellent case appreciation, science and technology papers, patents and computer software code copyright, defence etiquette, honour wall, and Innovation and Entrepreneurship Competition management policy. Through the openness of the platform, students can effectively obtain competition-related information. At the same time, based on this platform, a crosscollege and cross-discipline "Internet Plus" Innovation and Entrepreneurship Competition team is built, so that students can generate new ideas and actively realize them in unconstrained ideas. This platform enables students to give full play to their initiative, allowing them to start from the idea to the final development and implementation, and then they can participate in the final competition. Students are more involved and motivated in the process, and the development of Innovation and Entrepreneurship skills is effective.

The multi-level Elite Alumni Class includes "Little Star Special Class" and "Elite Alumni Class". freshmen were taught by senior in "Little Star Special Class". The successful alumni were invited to carry out the "Elite Alumni Class" for the students. The senior students can provide freshmen with some relevant courses' knowledge of their major, and can further tutor students who are less qualified. The outstanding alumni can extend the perspective of the students outside the campus to the society in which they will be employed in a few years. It allows students to further clarify the direction of their studies on campus.

\subsection{Building an Output-oriented Quality Assurance System Based on the OBE Mode}

Following the OBE concept, a continuous improvement mechanism has been built, which is composed two evaluation-improvement cycle systems - intramural and extramural. Among them, the intramural evaluation-improvement cycle is based on the mechanism for evaluating the rationality of curriculum system, mechanism for evaluating the achievement of course objectives 
and the mechanism for evaluating the achievement of graduation requirements. The evaluation work is carried out regularly, and the professional curriculum system, teaching syllabus, course teaching and course assessment are continuously improved based on the evaluation results. The extramural evaluation-improvement cycle is based on the follow-up feedback mechanism of graduates and the social evaluation mechanism. The achievement of the training objectives is regularly analysed and evaluated and used as a basis for continuous improvement of the professional training objectives, graduation requirements and their indicator points.

\section{CONCLUSION}

This paper is oriented to the " $5+5+1 "$ industrial development needs of Chengdu, and analyses the main contradictions and problems between supply and demand of industry and talent training by conducting in-depth and extensive research. In this regard, the training program and practical teaching system of applied talents in electronic information were innovatively reconstructed. Relying on the deep integration of "Government-EnterpriseSchool-City", a high-level comprehensive practice teaching platform is built. The quality and scale of the dual-tutor teachers' team are continuously being improved. Many measures to motivate and guide students to participate in engineering practice expect the training program has been taken, which has improved the utilization of students' spare time. At the same time, an Innovation and Entrepreneurship Competition platform and a multi-level Elite Alumni Class innovation cultivation system have been set up, and a crosscollege and cross-disciplinary EmergingEngineering "Internet Plus" competition team are formed. This measure has been applied and practiced well in the Chengdu University's in the School of Electronic Information Engineering and the School of Computer Science, and can provide effective reference for the cultivation of Electronic Information applied talents in other local universities

\section{AUTHORS' CONTRIBUTIONS}

Lijuan Xiong is responsible for conceptualization and contributes for writing the final draft and funding, Xiujun Zhang is responsible for original draft preparation, and Zhiqiang Zhang reviewed and edited the initial draft.

\section{REFERENCES}

[1] "Fudan consensus on the construction of 'Emerging engineering'", Research in Higher Education of Engineering, vol.2017, pp.10-11, January 2017.

[2] "'Emerging engineering' construction action line ('Tianjin University action')", Research in Higher Education of Engineering, vol.2017, pp.24-25, April 2017.

[3] "Comprehensively promote the construction of emergint engineering", China Higher Education, vol. 2021, pp.4, January 2021.

[4] Wu Ying, Xu Zhimin, Zhang Ling. "A new experiment teaching mode for machanics to meet the need of 'emerging engineering' talent training", Mechanics in Engineering, vol. 41, pp.86-90, February 2019.

[5] Xu Ming, "Reform and exploration of Internet plus and innovation and entrepreneurship courses in Universities", Education Modernization, vol. 7, pp.63-66, July 2020.

[6] Wang $\mathrm{Bu}$, "Exploration and practice of student-centered Hybrid Teaching under the background of emerging engineering", Journal of Higher Education, vol. 7, pp. 114-117, October 2021. 